UDC 621.9.06 - 229.331

S. Uminsky ${ }^{1}$, PhD, Assoc. Prof.,

O. Yakimov', DSc, Prof.,

L. Bovnegra' ${ }^{2}$ PhD, Assoc. Prof.,

N. Klimenko², PhD, Assoc. Prof.,

V. Balan ${ }^{2}$

${ }^{1}$ Odessa State Agrarian University, 13 Pantelejmovskaja Str., Odessa, Ukraine, 65074;

${ }^{2}$ Odessa National Polytechnic University, 1 Shevchenko Ave., Odessa, Ukraine, 65044; e-mail: ymoshi@ukr.net

\title{
ABOUT EFFECTIVE USE OF WHEELS WITH INTERMITTENT WORK SURFACE
}

\begin{abstract}
С.М. Уминський, О.О. Якімов, Л.В. Бовнегра, Н.М. Кліменко, В.О. Балан. До питання про ефективне використання кругів 3 переривчастою робочою поверхнею. Знизити теплонапружність процесу шліфування можна шляхом застосування кругів 3 переривчастою робочою поверхнею. При певному співвідношенні довжин виступів і западин і при певній їх кількості в пружній системі верстата можуть виникнути коливання великої амплітуди, що призводять до погіршення геометричних характеристик якості поверхнього шару оброблюваної деталі і збільшення розмірного зносу переривчастого шліфувального круга. Недостатня вивченість причин виникнення резонансу при переривчастому шліфуванні стримує широке застосування цих кругів. Метою роботи $\epsilon$ виявлення шляхів ефективного використання переривчастих кругів, при якому забезпечується безперервне самозагострення ріжучих зерен і їх своєчасне випадення з зв'язки, з одночасним обмеженням розмірного зносу шліфувального інструменту. Встановлено, що стійка робота пружної системи плоскошліфувального верстата, безприпальна обробка та ефективне знімання оброблюваного матеріалу можуть бути забезпечені при роботі переривчастими кругами з великою кількістю западин. Виявлена можливість забезпечення рівності знімань оброблюваного матеріалу і рівності лінійних зносів абразивних інструментів при суцільному і переривчастому шліфуванні. Експериментально встановлено, що для запобігання появи припалів на оброблюваних поверхнях необхідно при збільшенні поздовжньої подачі зменшувати глибину різання, або збільшувати число западин на переривчастому крузі. Розрахунково-експериментальним шляхом отримані криві рівних температур, що відокремлюють безприпальну зону від припальної. Встановлено, що зі збільшенням поперечної подачі при переривчастому шліфуванні область безприпальної обробки зміщується в бік збільшення кількості ріжучих виступів на робочій поверхні абразивного інструменту. Результати досліджень можуть бути використані при проектуванні шліфувальних кругів з переривчастою робочою поверхнею $\mathrm{i}$ призначення параметрів режиму різання при переривчастому шліфуванні.
\end{abstract}

Ключові слова: відносний знос, робоча поверхня круга, переривчасте шліфування, різальний виступ

S. Uminsky, O. Yakimov, L. Bovnegra, N. Klimenko,V. Balan. About effective use of wheels with intermittent work surface. To lower thermal stress of process of grinding, it is possible by application of wheels with intermittent working surface. At the certain parity of lengths of protrusions and cavities as well as at certain their quantities in elastic system of the machine tool the fluctuations of the big amplitude. This leads to a deterioration of the geometric characteristics of the surface quality of the workpiece and increases the dimensional wear of a discontinuous grinding wheel. The insufficient level of scrutiny of the reasons of occurrence of a resonance at grinding constrains wide application of these wheels. The purpose of the work is to identify ways efficiently to use intermittent wheels, which ensures continuous self-exacerbation of the cutting grains and their timely loss of bonding, while limiting the dimensional wear of the grinding tool. It is established, that stable operation of elastic system of the machine tool, processing and effective removing of material can be provided by work with intermittent wheels with the big number of cavities. The possibility of ensuring the equality of removals of the processed material and the equality of linear wear of abrasive tools with continuous and intermittent grinding is revealed. It has been experimentally established that in order to prevent the appearance of burns on the surfaces to be treated it is necessary to reduce the cutting depth or increase the number of cavities on an intermittent wheels as the longitudinal feed increases. The curves of equal temperatures, separating the non-burning zone from the burn-in zone, were calculated by experiment. It is established that with an increase in the transverse feed with intermittent grinding, the area of the non-burning operation is shifted towards increasing the number of cutting protrusions on the working surface of the abrasive tool. The results of the research can be used in the design of grinding wheels with a intermittent working surface and the assignment of the parameters of the cutting regime with intermittent grinding.

Keywords: relative wear, working surface of the wheel, intermittent grinding, cutting protrusion

Introduction. The appearance of grinding bursts and cracks on the treated surface is largely due to the loss of abrasive tool of cutting power. This is accompanied by an increase in surface temperatures to the fusion temperature of the treated material [1]. When grinding, high temperatures are formed, under the influence of which the physical-mechanical characteristics of the surface layer of the machined parts deteriorate. This leads to a decrease in the durability of machines during their operation.

Formulation of the problem. Increasing the cutting ability of a grinding tool in time can be by introducing into the cutting area ultrasonic oscillations of small amplitude [2, 3]. From the ultrasonic 
head, the oscillations to the abrasive tool are reported (normally to the working surface of the circle). The disadvantage of an ultrasound head is the adverse effects of ultrasound on human health.

Recently, experiments of vibrating grinding [4 - 10] are carried out, which is due to the introduction of an external forced oscillation into the elastic system of the machine. The presence of a forced oscillation in the elastic system reduces the resistance of the shingles and facilitates the process of chip formation, since friction of rest is replaced by friction of movement. This leads to a reduction in the likelihood of grinding defects. Because of the bulky equipment and the complexity of its installation on the machine, the vibration grinding has not been widespread. There is another way of introducing oscillations into the technological system of a grinder through the use of abrasive tools with a discontinuous working surface $[1,10,11]$. The moderate ability of intermittent circles is maintained for a long time due to the self-sharpening of the grinding tools and the exclusion of sticking the treated material to cutting grains.

In [1] it was established that the linear wear of intermittent abrasive wheels in the grinding process is $10 \ldots 50 \%$ higher than continuous (under other equal conditions). In [1], less wear resistance of intermittent circles is considered as a positive phenomenon, which contributes to the renewal of the microrelief of their working surface and the elimination of sowing. However, with an increase in the linear wear of the circle, the accuracy of the processing will be reduced. This is inappropriate for profile mortise grinding. Works [2, 3] dedicated of the issue of reducing the linear range of abrasive wear at the mortise grinding. During intermittent grinding parametric resonance may negatively affect the geometric quality surface detail that is processed. The parametric resonance is due to periodic changes (with the frequency of cutting bends over the part) of the total stiffness of the closed dynamic system of the grinding machine.

Works [4 - 9] are devoted to the problem of preventing parametric resonance. In these works, the struggle with parametric resonance is carried out by applying an elastic-damping fastening of the grinding wheel. Damping only slightly narrows the area of instability, but it is not able to limit the increase in the amplitude of oscillation in them.

The purpose of the work is to identify the conditions that ensure the maintenance of a developed microrelief of the working surface of a intermittent abrasive tool during the grinding process by limiting its linear wear.

Investigation of the efficiency of using interrupted wheels from the standpoint of dynamics of the grinding process. There are several external forced oscillations of the machine, which reduces the probability of grinding defects. This is due to the fact that, due to the replacement of frictional rest with frictional motion, the presence of these vibrations reduces the resistance of the shingles and facilitates the formation of chips.

The purpose of the work . On the basis of the analysis of previous studies to identify the conditions that in the process of grinding provide the maintenance of a developed microrelief working surface of the intermittent abrasive tool by limitation of its linear wear.

Fig. 1 and 2 show the totality of the values of $N$ - the ratio of the width of the slit $l_{2}$ to the length of the projection $l_{1}$ and the numbers of the cutting projections $n$ in the intermittent wheel, in which a parametric resonance arises in the elastic system of the grinding machine [13]. These sets $N$ and $n$ form the zones of parametric instability, which in Fig. 1 have the form of elongated elipses, and in Fig. 2 have the form of curved strips, separated by a dash. Data shown in these figures are obtained by calculations according to formulas $1-3$.

$$
\begin{gathered}
|L|>\frac{1+M}{2}, \\
L=\frac{e^{-h\left(\tau_{1}+\tau_{2}\right)}}{h\left(k_{2}+h \sin 2 k_{2} \tau_{1}\right)}\left[k_{1}^{2} \sin k_{1} \tau_{1} \sin k_{2} \tau_{2}-2 k_{1} k_{2} \cos k_{2} \tau_{1} \cos k_{1} \tau_{1} \cos k_{2}\left(\tau_{1}+\tau_{2}\right)-\right. \\
\left.-k_{2}^{2} \sin k_{1} \tau_{1} \sin \left(\cdot k_{2} \tau_{1}+k_{2} \tau_{2}\right)\right],
\end{gathered}
$$




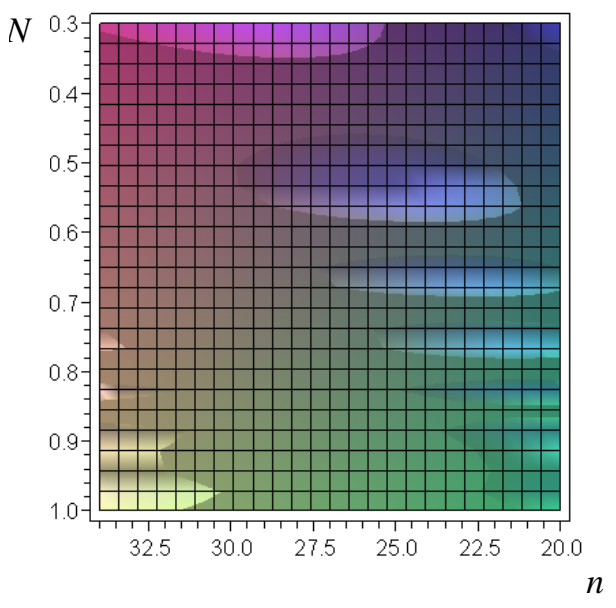

$a$

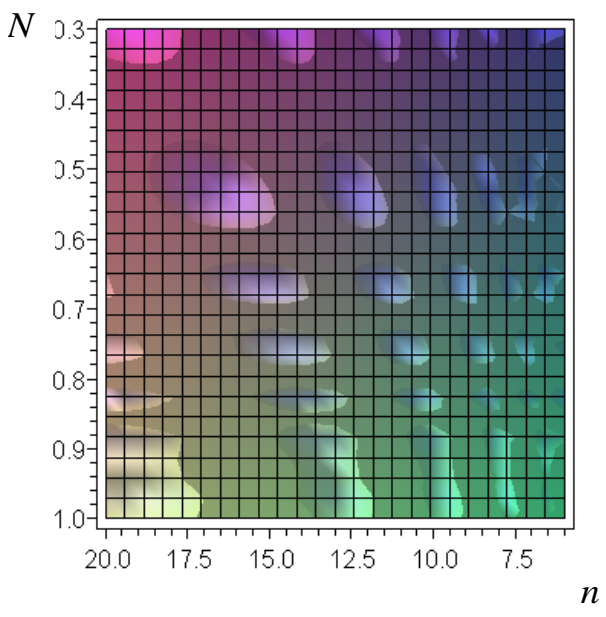

b

Fig. 1. Areas of the parametric instability of the elastic system of the grinding machine, constructed in a flat coordinate system, in which the abscissa is the number of cutting protrusions and cavities on the intermittent wheel, and the ordinate axis - the values of the ratio of the sizes of the cavities to the lengths of the protrusions: $20 \leq n \leq 34$ (a); $6 \leq n \leq 20$ (b), where $n$ is the number of grinding protrusions

$$
M=\frac{k_{1} k_{2} e^{-2 h\left(\tau_{1}+\tau_{2}\right)} \cos \left(2 k_{2}\left(\tau_{1}+\tau_{2}\right)\right)}{h\left(k_{2}+h \sin 2 k_{2} \tau_{1}\right)},
$$

where $\tau_{1}, \tau_{2}$ - the time of passing of the protrusion and the cavities of the intermittent wheel over the treated surface, sec.

$$
k_{1}=\sqrt{\frac{C_{0}}{m}+\frac{C_{0}\left(\frac{t_{l}}{t_{f}}-1\right)}{2 m}-h^{2},}
$$$$
k_{2}=\sqrt{\frac{C_{0}}{m}-\frac{C_{0}\left(\frac{t_{l}}{t_{f}}-1\right)}{2 m}-h^{2}[10,11],}
$$

$t_{l}$ - cutting depth, set to limb, m;

$t_{f}$ - actual depth of cutting, m;

$C_{0}$ - given stiffness of the elastic system of the machine, $\mathrm{N} / \mathrm{m}$;

$h$ - value that characterizing the extinction of oscillations over time, $1 / \mathrm{s}$;

$m$ - given weight of the grinding wheel is given, $\left(H \cdot \mathrm{s}^{2}\right) / \mathrm{m}$.

From Fig. 2 it is seen that with the increase in the number of slots on the working surface of the grinding tool, the zone of stable operation of the elastic system of the grinding machine (not shaded areas) expands.

Fig. 3 shows the curves of different emperors, separating the non-burning zone from the burning. From Fig. 3 it can be seen that with an increase in the longitudinal supply $S$ and, consequently, with increasing heat stress of the grinding process, area of the non-burning zone shifts in the direction of an increase in the number of cuts $n$ in the interrupted wheel. When comparing Fig. 2 and 3, it turns out that the boundaries of non-resonant and non-burning treatment areas have the same inclination and shape. From Fig. 3 shows that in order to prevent the formation of bursts with intermittent grinding 


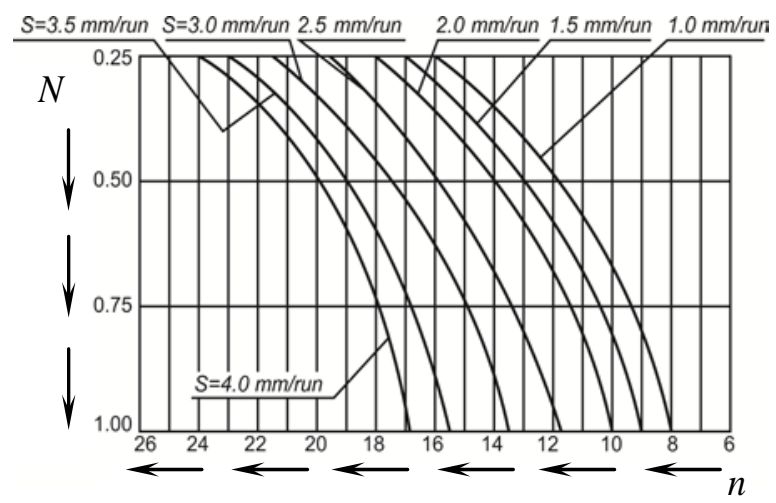

Fig. 3. Curves of equal temperatures separating the non-burning zone from the burner when grinding intermitted wheel 24A40CM1K1 of cemented steel $12 X 2 \mathrm{H} 4 \mathrm{~A}$ at the modes: $V_{\text {gem }}=10 \mathrm{~m} / \mathrm{min}, t=0.075 \mathrm{~mm}$,

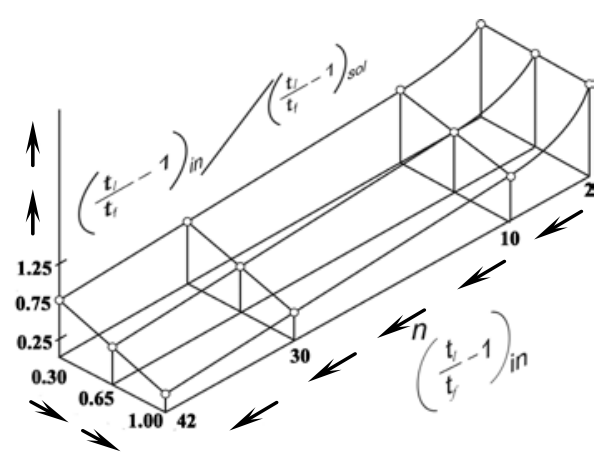

Fig. 4. Influence of the number of cavities and protrusions on a discontinuous circle and the ratio of their lengths to the magnitude of the indicator

$\left(t_{l} / t_{f}-1\right)_{\text {in }}$ characterizes the effectiveness of the abrasive tool (the smaller the value of this indicator, the greater the efficiency of the wheel) $1 \mathrm{~mm} / \mathrm{run} \leq S \leq 4 \mathrm{~mm} / \mathrm{run}, V_{\mathrm{kr}}=30 \mathrm{~m} / \mathrm{s}$

that carried out with constant transverse feed S, it is necessary to increase the value of the ratio of the width of the depression $l_{2}$ to the length of the depression $l_{1}$ with decreasing number of cavities $n$ in the wheel.

The $\left(\frac{t_{l}}{t_{f}}-1\right)$ parameter in formula (2) and (3) can be used to evaluate the performance of the abrasive wheel; the experimental determination of this indicator is reduced to the measurement of the true size of the removal of the material being processed. On the basis of experimental data on the true measurements in intermittent and continuous grinding [11 - 13], dependences were constructed

$$
\begin{aligned}
& \left(\frac{t_{l}}{t_{f}}-1\right)_{\text {in }} /\left(\frac{t_{l}}{t_{f}}-1\right)_{\text {sol }}=f(N), \\
& \left(\frac{t_{l}}{t_{f}}-1\right)_{\text {in }} /\left(\frac{t_{l}}{t_{f}}-1\right)_{\text {sol }}=f(N), \\
& \left(\frac{t_{l}}{t_{f}}-1\right)_{\text {in }} /\left(\frac{t_{l}}{t_{f}}-1\right)_{\text {sol }}=f(n) .
\end{aligned}
$$

These dependencies indirectly indicate how much the cutting power of a interrupted tool is better than the cutting ability of a continuous wheel. The smaller the ratio of $\left(\frac{t_{l}}{t_{f}}-1\right)_{\text {in }} /\left(\frac{t_{l}}{t_{f}}-1\right)_{\text {sol }}$, the better the interrupted wheel works compared to the continuous one.

Analysis of Fig. 4 shows that the efficiency of interrupted wheel (as compared to continuous) increases with the increase in the number of slits on the working surface of the grinding tool and with the increase in the ratio of the width of the slit $l_{2}$ to the length of the cutting lip $l_{1}$. The above data indicates that the interrupted wheel works in a self-sharpening mode and has more sharp cutting edges than a solid wheel. In addition, the process of discontinuous grinding with large thicknesses of slices provides higher processing performance.

In the process of grinding with wheels of the intermittent working surface, impact loads affect the cutting grains. The largest load is grain, located near the front cutting of the edge. These grains are intensively expanding with the formation of bonds. On the cutting faces of the working surface, a certain angle of attack is formed against the cutting plane (Fig. 5). Changing of the cutter profile changes the drag-drop layout. From Fig. 5 it is seen that the plates, simulating the normal components of the infinitely thin layers of the removing drop, are introduced into the working surface of the circle with different velocities at different parts of the contact area of the abrasive tool with the material being processed: $V_{\text {det.12 }}^{\prime} \triangleleft V_{\text {det.17 }}^{\prime} \triangleleft V_{\text {det.22 }}^{\prime}$. 
The difference between these velocities is due to the difference in the values of the sinuses of the input angles of the plates in the working surface of the circle $V_{\text {det }}^{\prime}=V_{\text {det }}^{\prime} \cdot \sin \alpha$.

The maximum speed corresponds to the maximum coordinate $l_{22}=\sqrt{2 R_{\text {cir }} t_{22}}$ for this case $V_{\text {det }}^{\prime}=V_{\text {det }} \frac{l_{22}}{R_{\text {cir }}}=V_{\text {det }} \sqrt{\frac{2 t}{R_{\text {cir }}}}$.

During the passage of the cavity, the interrupted wheel will result in the displacement of the plates in the radial direction by the value of $h$. During the course of the cutting edge, the speed

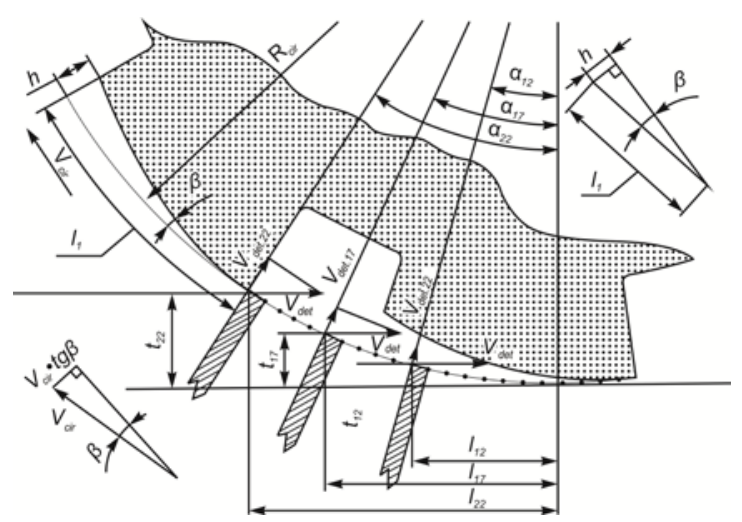

Fig. 5. Scheme of intermittent grinding of removal of material increases by amount $V_{\text {cir. }}=\operatorname{tg} \beta, V_{\text {det. }}^{\prime \prime}=V_{\text {det }}^{\prime}+V_{\text {cir }} \operatorname{tg} \beta$, where $\operatorname{tg} \beta=\frac{h}{l_{1}}$.

Running allowance $h$ is proportional to the length of the wheel cavity $l_{2}$

$$
h=V_{\text {det }} \tau_{2} \text {, where } \tau_{2}=\frac{l_{2}}{V_{\text {cir }}} .
$$

Finally parameters $h$ and $V_{\text {det }}^{\prime \prime}$ will be described

$$
\begin{gathered}
h=l_{2} \frac{V_{\mathrm{det}}^{\prime}}{V_{c i r}}, \\
V_{\text {det }}^{\prime \prime}=V_{\text {det }}^{\prime}\left(1+\frac{l_{2}}{l_{1}}\right) .
\end{gathered}
$$

The maximum cut-off plane $H_{\max }$ for planar intermittent grinding by the elbow wheel is determined [13]

$$
H_{\max }=\sqrt[3]{\frac{630 \cdot \pi^{-3} \cdot V_{\mathrm{det}}}{\tan \gamma \cdot m \cdot V_{\text {cir }}} \cdot \sqrt{\frac{2 t}{R_{\text {cir }}}\left(1+\frac{l_{2}}{l_{1}}\right)}},
$$

where: $\gamma$ - half of the circle at the vertex of the cutting grain, $\mathrm{m}$ is the relative concentration of elbora in the circle,

$\bar{x}$ - grains of the circle,

$t$ - the depth of cutting.

Imagining the speed of the details $V_{\text {det }}$ in the form $V_{\text {det }}=\frac{Q}{B t}$ (where $Q$ - processing performance, $B$ - the width of the grinding wheel), we obtain

$$
H_{\max }=\sqrt[3]{\frac{630 \cdot \pi \cdot x^{-3}}{\tan \gamma \cdot m \cdot V_{\text {cir }}} \cdot \sqrt{\frac{Q \cdot V_{\mathrm{det}} \cdot 2}{B \cdot R_{\text {cir }}}} \cdot\left(1+\frac{l_{2}}{l_{1}}\right)} .
$$

In order for the performance of intermittent grinding $Q_{i n}$ to be equal to the productivity of continuous grinding $Q_{\text {sol }}$ at a constant value of the maximum reduced thickness $\left(H_{\text {max.in. }}=H_{\text {max.sol. }}\right)$, the required speed of the part with intermittent grinding will decrease by $\left(1+\frac{l_{2}}{l_{1}}\right)^{2}$ times, that is, 


$$
V_{\text {det.in }}=\frac{V_{\text {det.sol }}}{\left(1+\frac{l_{2}}{l_{1}}\right)^{2}} .
$$

The depth of grinding $t_{\text {in }}$ under the condition $Q_{i n}=Q_{\text {sol }}$ should be related to the depth of grinding $t_{\text {sol }}$

$$
t_{\text {in }}=t_{\text {sol }}\left(1+\frac{l 2}{l 1}\right)^{2} \text {. }
$$

Conditions (6) and (7) are provided by reducing the linear wear of the intermittent circle to the level of wear of a wheel with a continuous working surface (without reducing the processing efficiency).

Table shows the experimental values of the specific wear of elbow wheels during mortise grinding of specimens from steel R6M5 $8 \mathrm{~mm}$ in width, $150 \mathrm{~mm}$ in length on a 3G71M flat grinding machine by continuous and intermittent $(n=12, N=0.455)$ wheels 1 A1 $200 \times 75 \times 5 \times 20$ KR 160/125 B8 100 during a 7-minute period in two modes.

Table

\begin{tabular}{|c|c|c|c|c|c|c|c|c|}
\hline$\tau$, min & 1 & 2 & 3 & 4 & 5 & 6 & 7 & Grinding mode \\
\hline$q_{\text {sol }} ; \mathrm{mg} / \mathrm{g}$ & 12.80 & 10.74 & 10.04 & 9.66 & 9.42 & 8.47 & 7.90 & \multirow{2}{*}{$\begin{array}{c}\text { Mode № } 1 \\
t=0.03 \mathrm{~mm} \\
V_{\text {cir }}=30 \mathrm{~m} / \mathrm{s} \\
V_{\text {dem. }}=6.00 \mathrm{~m} / \mathrm{min}\end{array}$} \\
\hline $\begin{array}{c}q_{\mathrm{sol}} \cdot 1 \\
\mathrm{mg} / \mathrm{g}\end{array}$ & 10.40 & 8.80 & 8.00 & 7.80 & 7.70 & 6.70 & 6.50 & \\
\hline $\begin{array}{l}Q_{\mathrm{sol}} \cdot 2 \\
\mathrm{mg} / \mathrm{g} \cdot\end{array}$ & 8.00 & 6.80 & 6.20 & 6.00 & 6.00 & 5.20 & 5.00 & $\begin{array}{c}\text { Mode № } 2 \\
t=0.063 \mathrm{~mm} \\
V_{\text {cir }}=30 \mathrm{~m} / \mathrm{s} \\
V_{\text {det. }}=2.83 \mathrm{~m} / \mathrm{min}\end{array}$ \\
\hline$q_{\text {sol }} / q_{\text {in. } 1}$ & 1.23 & 1.22 & 1.25 & 1.24 & 1.21 & 1.26 & 1.21 & \multirow{3}{*}{ net. } \\
\hline$q_{\text {sol }} / q_{\text {in. } 2}$ & 1.60 & 1.58 & 1.62 & 1.61 & 1.57 & 1.63 & 1.58 & \\
\hline$q_{\text {sol }} / q_{\text {in. } 2}$ & 1.00 & 0.97 & 1.05 & 1.03 & 0.98 & 1.02 & 0.95 & \\
\hline
\end{tabular}

Experimental values of specific wear of elbow wheels during mortise grinding of R6M5 steel samples

In mode № 1 a comparative estimation of distant wear of continuous and intermittent elbow wheels was conducted. From the table it is seen that the specific wear of intermittent circles is approximately 1.23 times less than the wear of continuous circles.

In mode № 2 the depth of cutting and speed of the details of $V_{\text {det.in. }}$. were determined by the formulas (6) and (7). These operating parameters ensure the equality of linear wear of continuous and intermittent wheels and the equality of removable metal when grinding these wheels on the modes number 1 and number 2, respectively.

Table shows that despite the equality of linear wear of continuous and intermittent elbow tools ( $h_{\text {sol }} / h_{\text {in. } 2} \approx 1$ ), their individual wear varies: $q_{\text {sol }} / q_{\text {in. } 2} \approx 1.62$. Reducing the specific wear of the intermittent wheel $q_{i n .2}$ in comparison with the continuous $q_{\text {sol }}$ wheel can be explained by a decrease in the length of the working surface of the tool due to the presence of cavities on it.

Investigation of the efficiency of using intermittent wheels from the standpoint of heat stress of the grinding process.

Fig. 6, 7, 8, 9 shows the experimental graphs by which one can answer the question whether grinding regimes calculated by formulas (6) and (7) will ensure the equality of processing performance and the equality of linear wear of grinding wheels with continuous and intermittent grinding. Will it ensure the temperature equality in the cutting zone?

Fig. 6 shows the curves, each point of which is a combination of mode parameters (cutting depth t, component speed $V_{\text {det }}$ and transverse feed $S$ ), continuous grinding of 24A40 CM1 K1 cemented steel 2X2H4A, which provides non-burning treatment. 


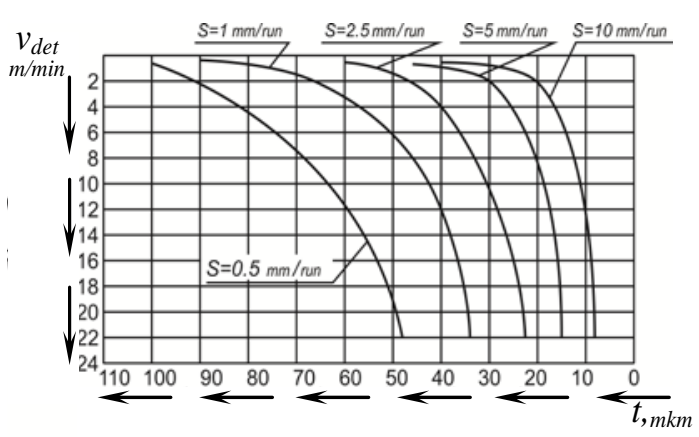

Fig. 6. Curves of equal temperatures, separating the non-burner zone from the burner when grinding a continuous wheel $24 A 40 C M 1 K 1$ of the cemented steel $12 \mathrm{X} 2 \mathrm{H} 4 \mathrm{~A}$

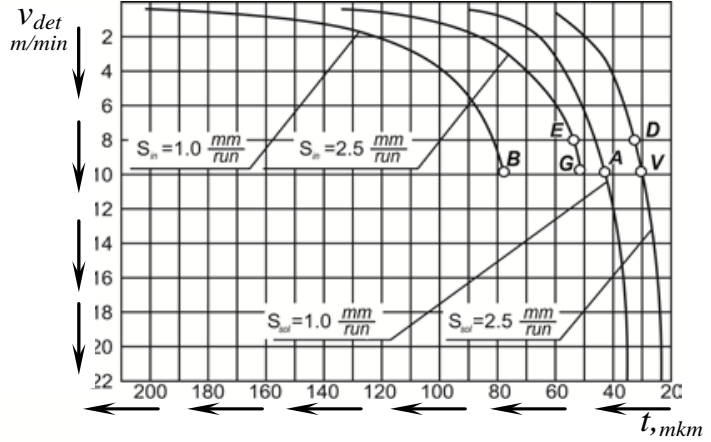

Fig. 7. Curves corresponding to the boundaries of the non-burning zone of continuous grinding and modes of intermittent grinding, which ensures a reduction in the wear of the intermittent wheel $24 A 40 C M 1 K 1(N=0.5)$ to

the level of wear of a continuous wheel of the same characteristics without reducing the processing efficiency

Each of these curves is the limit of the non-burning zone (the zone is located to the right side of this limit). From Fig. 6 it can be seen that in order to provide a non-birning grinding that carried out with a constant transverse feed $S$, it is necessary to increase the depth of the cutting $t$ by reducing the speed of the part $V_{\text {det }}$.

Fig. 7 the parameters of the modes of non-burning continuous grinding of cemented steel $12 \mathrm{X} 2 \mathrm{H} 4 \mathrm{~L}$ in the wheel $24 \mathrm{~A} 40 \mathrm{CM} 1 \mathrm{~K} 1$ (two right curves) and parameters of grinding modes in a intermittent wheel are given. $\left(\frac{l_{2}}{l_{1}}=0.5\right)$ of the same characteristics, calculated according to formulas (6) and (7), which ensure the equality of removal of material and the equality of linear wear of abrasive tools with continuous and intermittent grinding (two left curves).

From Fig. 7 it is seen that continuous grinding that carried out in the mode $t=0.03 \mathrm{~mm}$. $V_{\text {det }}=10 \frac{\mathrm{m}}{\mathrm{min}}, S=2.5 \frac{\mathrm{mm}}{\text { run }}$, is not accompanied by the appearance of burns on the treated surfaces (point $B$ ).

In the analysis of Fig. 7, the question may arise whether the burns will occur if the grinding is performed intermittently with a cutting depth $\mathrm{t}=0.052 \mathrm{~mm}(\operatorname{dot} G)$. A similar question can be asked regarding the points $A$ (non-spurious grinding at this point is carried out by a continuous wheel with a depth of cutting $t_{c n}=0.043 \mathrm{~mm}$ ) and $B$ (depth of intermittent grinding $t_{c n}=0.078 \mathrm{~mm}$ ). Answers to these questions we could obtain from the experimental graphs $T=f(t)$ presented in Fig. 8. The identical points in Fig. 7 and 8 correspond to identical grinding conditions (parametric cutting patterns, abrasive tool characteristics, marks of machined steel) and, consequently, identical temperatures in the cutting zone.

Experimental data presented in Fig. 8, confirm the equality of processing performance, as well as linear wear of wheels and temperatures arising from continuous and intermittent grinding on modes satisfying conditions (6) and (7). An indirect confirmation is the data presented in Fig. 9 In this case, not the equality of temperatures is confirmed, but the power equal to that applied when grinding on the modes satisfying the requirements (6) and (7).

Experimental dependencies $T=f(t)$ (Fig. 8) are an indirect confirmation of the graphs presented in Fig. 3. Comparison of Fig. 8 and Fig. 3 shows that when grinding an intermittent wheel $N=l_{2} / l_{1}=0.5$ to provide a non-burning treatment with an increase in longitudinal processing from $S=1.0 \frac{\mathrm{mm}}{\text { run }}$ to $S=2.5 \frac{\mathrm{mm}}{\text { run }}$ necessary, or to reduce the depth of cutting from $t=0.08 \mathrm{~mm}$ to $t=0.06 \mathrm{~mm}$, or increase the number of cavities on intermittent wheel from $n=12$ to $n=16$. 


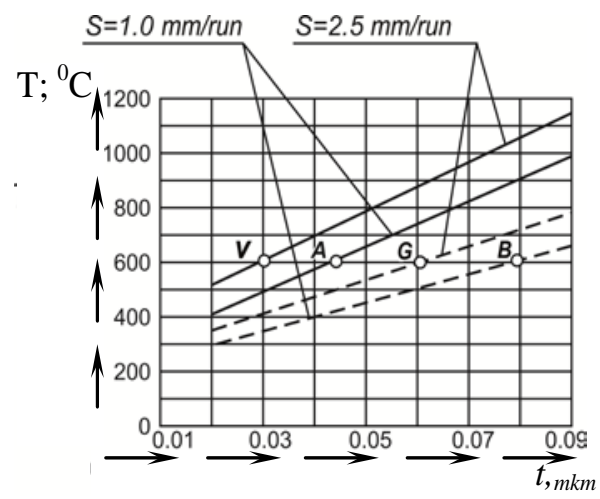

Fig. 8. Dependence of the grinding temperature on the cutting depth when grinding with continuous (continuous lines) and intermittent $(n=12 ; N=0.5)$ (dashed lines) wheels 24A40SM1K1 made of cemented steel $12 X 2 \mathrm{H} 4 \mathrm{~A}$ at $V_{\text {gem }}=10 \mathrm{~m} / \mathrm{min} ; V_{\mathrm{kp}}=30 \mathrm{~m} / \mathrm{s}$

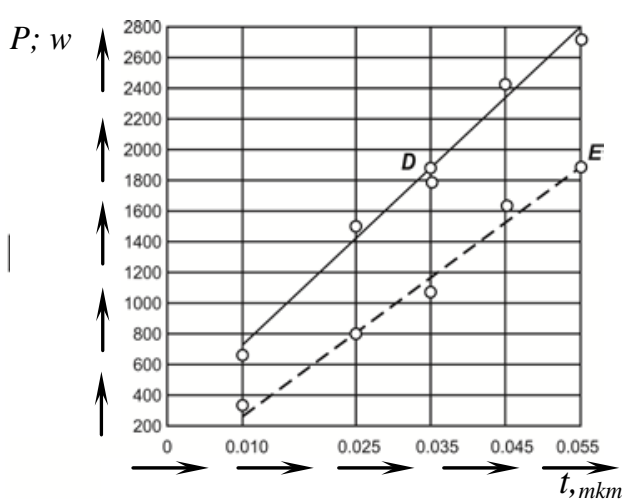

Fig. 9. The dependence of the power expended on development from the depth of the mortise grinding of steel P6M5 continuous (continuous line) and intermittent (line) $(n=12 ; N=0.455)$ with circles $200 X 75 X 5 X 20$ KP160/125 B8 100 at $V_{\text {gem }}=8 \mathrm{~m} / \mathrm{min}, V_{k p}=30 \mathrm{~m} / \mathrm{s}$

Conclusions. It has been established that stable operation of the elastic system of the flatgrinding machine, non-burning processing and effective removal of the processed material can be provided with intermittent wheels with a large number of cavities. Possibility of the equality of removals of processed metherial and the equality of linear wear of abrasive tools with continuous and intermittent grinding has been revealed.

\section{Література}

1. Набока Е.В. Технологии в машиностроении с использованием ультразвука. Физические $u$ компьютерные технологии в народном хозяйстве : труды 6-й международной научно-техн. конференции. Харьков : ХНПК «ФЭД», 2002. С. 152-154.

2. Набока Е.В. Анализ влияния ультразвуковых колебаний на процесс алмазно-искового шлифовки. Физические и компьютерные технологии в народном хозяйстве : труды 8-й международной научно-техн. конференции. Харьков : ХНПК «ФЭД», 2003. С. 132-133.

3. Азарова Н.В. Исследование параметров единичных срезов при плоском шлифовании с вибрациями. Надёжность инструмента и оптимизаџия технологических систем : сборник науч. работ. 2005. №17. С. 49-55.

4. Азарова Н.В. Определение параметров единичных срезов при плоском шлифовании с вибрациями с учётом разновысотных положений зёрен. Машиностроение и машиноведение. Научные труды Донеичкого национального технического университета. 2004. С. 9-16.

5. Матюха Г.П., Азарова Н.В. Влияние радиальных вибраций шлифовального круга на форму среза и число контактирующих зерен. Сверхтвердые материаль. 2004. №5. С. 58-64.

6. Матюха, Г.П., Азарова Н.В. Влияние колебания оси шлифовального круга на условия контактирования абразивного зерна с обрабатываемой поверхностью. Прогрессивные технологии и системы машиностроения: междунар. сборник научных трудов Донецикого национального технического университета. Донецьк. 2004. №25. С. 105-110.

7. Матюха, Г.П., Габитов В.В., Полтавец В.В. Длина дуги контакта единичного зерна с заготовкой при плоском шлифовании с осевыми колебаниями круга. Машиностроение и машиноведение. Научные труды Донецкого национального технического университета. 2007. С. 21-30.

8. Наддачин, В.Б. Причины вибрации шпиндельной системы станка и их влияние на процесс шлифовки. Физические $и$ компьютерные технологии в нородном хозяйстве : труды 6-й международной научно-техн. конференции. Харьков : ХНПК «ФЭД». 2003. С. 132-133.

9. Новиков Г.В. Физическая сущность и эффективность вибрационного резания. Физические $и$ компьютерные технологии в нородном хозяйстве : труды 7-й международной научно-техн. конференции. Харьков : ХНПК «ФЭД». 2003. С. 85-87.

10. Филин А.Н. Влияние износа шлифовальных кругов на точность формы фасонных профилей. Химическое и нефтяное матиностроение. 1981. №11. С. 27-28. 
11. Новиков Ф.В., Якимов А.А. К вопросу о сущности прерывистого шлифования. Резание $u$ инструмент в технологических системах: междунар. научно-техн. сборник. Харьков : НТУ «ХПИ», 2001. С. 177-182.

12. Якімов О.О., Тонконогий В.М., Бовнегра Л.В., Тігарєв В.М. Розширення можливості застосування переривчастих шліфувальних кругів на керамічній зв'язці. Сучасні технології в машинобудуванні: збірник наук. пращъ. Харків: НТУ «ХПІ». 2016. №11. С. 64-73.

13. Тонконогий В.М., Якимов А.А., Бовнегра Л.В. Динамика прерывистого шлифования. Резание $u$ инструмент в технологических системах: междунар. научно-техн. сборник. Харьков : НТУ «ХПИ». 2015. №85. С. 288-295.

\section{References}

1. Naboka, E.V. (2002). Technologies in mechanical engineering using ultrasound. Physical and computer technologies in the national economy: works of the 6th International Science and Technology conf. (pp. 152-154). Kharkiv: KhNPK “FED”.

2. Naboka, E.V. (2003). Analysis of the influence of ultrasonic vibrations on the diamond grinding. Physical and computer technologies in the national economy: the works of the 8th International Science and Technology. conf. (pp. 132-133) Kharkiv: KhNPK “FED”.

3. Azarova, N.V. (2005). Investigation of the parameters of unit slices for flat grinding with vibrations. Reliability of the tool and optimization of the technological systems: coll. of scientific works Kramatorsk. DGMA, 17, 49-55.

4. Azarova, N.V. (2004). Determination of the parameters of unit slices for flat grinding with vibrations taking into account heterogeneous positions of grains. Scientific works of Donetsk National Technical University. Series: mechanical engineering and machine science, 9-16.

5. Matyukha, G.P., \& Azarova, N.V. (2004). Influence of radial vibrations of the grinding wheel on the cutoff shape and the number of contacting grains. Superhard materials, 5, 58-64.

6. Matyukha, G.P., Matyukha, P.G. \& Azarova, N.V. (2004). Influence of the oscillation of the axis of the grinding wheel on the conditions contacting abrasive grain with the processing surface. Progressive Technologies and Systems of Mechanical Engineering: Intern. Coll.of scientific works, 25, 105-110.

7. Matyukha, G.P., Gabitov, V.V. \& Poltavets, V.V. (2007). The length of the contact arc of the unit grain with the billet at the flat grinding with axial oscillations of the circle. Scientific works of the Donetsk national. tech. university. Series: mechanical engineering and machine science, 21-30.

8. Naddachin, V.B. (2003). The causes of vibration of the spindle system of the machine and their influence on grinding process. Physical and Computer Technologies in National economy: works of the 6th International Science and Technology. conf. (pp. 132-133) Kharkiv: KhNPK “FED”.

9. Novikov, G.V.(2003). Physical essence and efficiency of vibratory cutting. Physical and computer technologies in the native economy: works of the 7th International Science and Technology conf. (pp. 85-87) Kharkiv: KhNPK “FED”.

10. Filin, A.N. (1981). Influence of wear of grinding wheels on the accuracy of shaped shapes profiles. Chemical and Petroleum Engineering, 11, 27-28.

11. Novikov, F.V. \& Yakimov A.A. (2001). To the question of the essence of intermittent grinding. Cutting and tool in technological systems: inter. scientific-tech, 177-182.

12. Yakimov, O.O., Tonkogony, V.M., Bovnegra, L.V., \&. Tigarev, V.M. (2016). Expansion of the possibility of using interrupted grinding wheels on a ceramic bond. Modern technologies in mechanical engineering: sb. sciences works. 11. 64-73.

13. Tonkonogiy, V.M., Yakimov, A.A. \& Bovnegra, L.V. (2015). Dynamics of discontinuous grinding. Cutting and tools in technological systems: international scientific-tech. sb., 85, 288-295.

Уминський Сергій Михайлович; Uminsky Sergey, ORCID: https://orcid.org/0000-0002-7767-8405

Якімов Олексій Олександрович; Yakimov Olekcii, ORCID: https://orcid.org/0000-0003-2096-4555

Бовнегра Любов Віталіївна; Bovnegra Liubov, ORCID: https://orcid.org/0000-0003-0429-2816

Клименко Наталія Миколаївна; Klimenko Natalia, ORCID: https://orcid.org/0000-0003-1841-276X

Балан Володимир Олександрович; Balan Volodymyr, ORCID: https://orcid.org/0000-0001-6183-9633 